Dicle Tıp Dergisi / Dicle Med J (2018) 45 (1) : 59 - 69

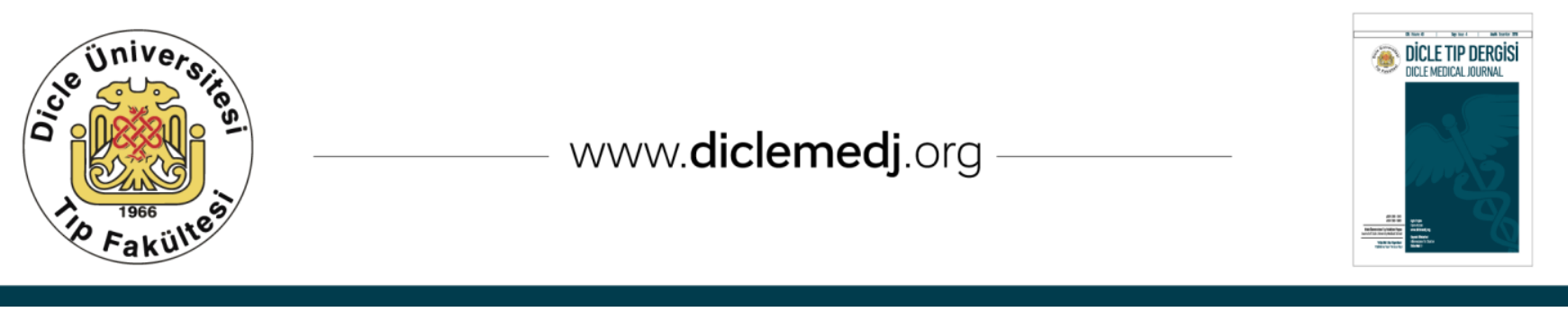

Özgün Araștırma / Original Article

\title{
Beslenme alışkanlıkları ve fiziksel aktivite düzeylerinin analizi: Marmara üniversitesi öğretim üyeleri üzerine bir çalışma
}

\author{
Müge Arslan1 \\ 1 Bahçeșehir Üniversitesi Beslenme ve Diyetetik bölümü, İstanbul, Türkiye ORCID: 0000-0003-1305-5126 \\ Geliş: 10.10.2017, Revizyon: 20.02.2018, Kabul Tarihi: 21.02.2018
}

Özet

Amaç: $\mathrm{Bu}$ çalışma, akademisyenlerin beslenme alışkanlıkları ve fiziksel aktivite düzeylerinin incelenmesi amaçlanmıştır.

Yöntemler: Araştırma tanımlayıcı tipte bir araştırmadır. Marmara Üniversitesi Haydarpaşa Kampüsü’ndeki Tıp Fakültesi Temel Bilimleri, Eczacılık Fakültesi, Hemşirelik Yüksekokulu ve Hukuk Fakültesinde Aralık 2013-Nisan 2014 tarihleri arasında görev yapan 225 öğretim elemanına yüz yüze anket uygulanmış ve boy ile kiloları ölçülmüş ve öğrencilerin Vücut Kitle İndeksleri-VKİ (ă̆ırlık $(\mathrm{kg}) /$ boy $^{2}\left(\mathrm{~m}^{2}\right)$ hesaplanmıștır. VKİ değeri 30 üstü olanlar obez olarak değerlendirilmiştir.

Bulgular: Öğretim elemanlarının \%66,2'si kadın, \%33,8'i erkektir. Katılımcıların, \%23,6'sının Tıp Fakültesi'nde, \%28,0'ının Eczacılık Fakültesi'nde, \%13,7'sinin Hemşirelik Yüksekokul' unda ve \%34,7'sinin Hukuk Fakültesi'nde görev yapmakta olduğu bulunmuştur. Katılımcıların ; \%4,9'u zayıf , \%58,6'sı normal kilolu , \%29,8'i fazla kilolu ve $\% 6,7$ 'si obez olarak bulunmuştur. Fazla kilolu ve obezler birlikte değerlendirildiğinde öğretim elemanlarının $\% 41,4$ 'ünün kilosunun normalin üzerinde olduğu görülmektedir.

Obezite oranı en yüksek bölüm; Eczacılık Fakültesinde iken $(\% 9,6)$, bu oran Tıp Fakültesi öğretim üyelerinde \%3,7 ile daha düşüktür. Hukuk Fakültesinde hiç zayıf katılımcı yoktur. Kilosu normalin üzerinde olanların oranı \%33,3 ile Eczacılık Fakültesinde en yüksek iken, Hemşirelik Yüksekokulunda bu oran \%12,9 ile en düșüktür. Obezite bakımından en yüksek oran \%9,6 ile Eczacılık Fakültesinde iken, en düşük oran \%3,7 ile Tıp Fakültesindedir.

DOI: $10.5798 /$ dicletip.407246

Yazışma Adresi / Correspondence: Müge Arslan, Bahçeşehir Üniversitesi Beslenme ve Diyetetik bölümü, İstanbul, Türkiye e-mail: dyt_muge@hotmail.com 
Katılımcıların öğün atlama durumlarına göre dağılımları incelendiğinde; öğretim elemanlarının önemli bir oranının \%72,0’ı sürekli öğün atladığı görülmektedir. Bazen öğün atlayanlarda dikkate alındığında bu oran \% 94,7'ye çıkmakta, ögün atlamayanların oranı çok düşük kalmaktadır.

Tıp Fakültesi $(71,7 \pm 35,29)$ en yüksek yağ alımına sahip bölüm iken, Hukuk Fakültesi $(57,8 \pm 17,72)$ günlük en düşük yağ alımına sahip bölümdür. Eczacılık Fakültesi'nin günlük kalori $(1420,53 \pm 337,26)$ ve protein alımı $(85,5 \pm 33,66)$, diğer bölümlere göre daha yüksek iken, Tıp Fakültesinin günlük karbonhidrat alımı $(123,6 \pm 46,11)$ diğer bölümlere göre daha yüksektir.

Sağlık alanında görev yapanlar en yüksek günlük kalori $(1388,9 \pm 332,65)$ ve yağ alımına $(68,5 \pm 26,02)$ sahip grup iken, Hukuk alanında görev yapanlar en düşük günlük kalori $(1282,5 \pm 326,44)$ ve yağ alımına $(57,8 \pm 17,85)$ sahiptir. Sağllk alanında görev yapanların günlük karbonhidrat $(117,4 \pm 37,82)$ ve protein alımları $(79,7 \pm 31,61)$ Hukuk alanında görev yapanlara göre daha yüksek iken bunlar arasında istatistiksel olarak anlamlı fark yoktur (p>0,05).

Öğretim üyelerinin aktivite düzeyi değerlendirildiğinde \% 66,7'sinin in aktif olduğu görülmüştür. Minimal düzeyde aktif olanların oranı \% 30,7 iken çok aktif olanların oranı yalnızca \% 2,6'dır.

Sonuç: Sağlık alanında görev yapan öğretim elemanları en yüksek günlük kalori ve yağ alımına sahip iken Hukuk Fakültesinde görev yapanlar en düşük günlük kalori ve yă̆ alımına sahiptir. Öğretim elemanların \%6,7'si obezdir ve obezite oranı en yüksek bölüm; Eczacılık Fakültesinde bulundu $(\% 9,6)$. Sağlıklı ve dengeli beslenme ile ilgili eğitim verilebilir.

Anahtar kelimeler: Beslenme alıșkanlıkları, fiziksel aktivite düzeyi, vücut kitle indeksi, besin alımı, fiziksel aktivite alışkanlıkları

\section{Analysis of eating habits and physical activity levels: A study on Marmara University faculty academicians}

\section{Abstract}

Objective: This study aimed to examine the eating habits and physical activity levels of academicians.

Methods: Research is descriptive type research. A face-to-face questionnaire was administered to 225 faculty members from Marmara University Haydarpaşa Campus in Basic Sciences, Faculty of Pharmacy, School of Nursing and Faculty of Law between December 2013 and April 2014 and their height and weight were measured and the students' Body Mass Index- $\mathrm{kg}) / \mathrm{height}\left(\mathrm{m}^{2}\right)$ were calculated and those with a BMI greater than 30 were considered obese.

Findings: $66.2 \%$ of theacademicianarefemaleand $33.8 \%$ are male. It was found that $23,6 \%$ of the participants were in the Faculty of Medicine, $28,0 \%$ in the Faculty of Pharmacy, $13,7 \%$ in the School of Nursing and 34,7\% in the Faculty of Law. Participants; $4.9 \%$ were weak, $58.6 \%$ were normal weight, $29.8 \%$ were overweight and $6.7 \%$ were obese. When overweight and obese are evaluated together, it is seenthat $41.4 \%$ of the academician are above the normal weight.

Obesity rate is highest; While at the Faculty of Pharmacy $(9,6 \%)$, this rate is lower by $3.7 \%$ in Faculty of Medicine Faculty members. There are no weak participants in the Faculty of Law. While the ratio of those who are above normal is 33.3\%, this ratio is the highest in the Faculty of Pharmacy, while it is the lowest in the School of Nursing with $12.9 \%$. The highest rate of obesity is in the Faculty of Pharmacy with $9.6 \%$ while the lowest rate is in the Faculty of Medicine with $3.7 \%$.

When the distribution of participants according to their meal times is analyzed; it is observed that $72.0 \%$ of the academicians have consistently missed meals. Occasionally, when taking into consideration in meals, this ratio increases to $94.7 \%$ and the rate of those who do not skip meals is very low. The Faculty of Medicine $(71,7 \pm 35,29)$ has the highest fat intake whereas the Faculty of Law $(57,8 \pm 17,72)$ has the lowest fat intake per day. Daily intake of carbohydrates $(123,6 \pm 46,11)$ was higher in the Faculty of Pharmacy than in the other departments, while daily calories $(1420,53 \pm 337,26)$ and protein intake $(85,5 \pm 33,66)$ higher than the parts.

While those working in the field of health were the group with the highest daily calories $(1388.9 \pm 332.65)$ and fat intake $(68.5 \pm$ 26.02), those working in the field of law had the lowest daily calories $(1282.5 \pm 326.44)$ and fat intake $(57,8 \pm 17,85)$ When the activity level of the academician was evaluated, $66.7 \%$ of them were active, while the proportion of those who are active at the minimum level is $30.7 \%$, the rate of those who are very active is only $2.6 \%$.

Result: While faculty members in the health field have the highest daily calorie and fat intake, those working at the Faculty of Law have the lowest daily calorie and fat intake.6.7\% of the teaching staff were obese and the highest rate of obesity; He was at the Faculty of Pharmacy $(9,6 \%)$. Training on healthy and balanced nutrition can be given.

Keywords: eating habits, physical activity level, body mass index, food intake, physical activity habits. 


\section{GíRIŞ}

Beslenme, anne karnındaki süreçten, yaşamın sonuna kadar insan sağlığı için en önemli etkenlerden birisidir. Yaşanılan sürecin ilerlemesiyle beraber, arkadaş çevresi, aile yapısı, meslek gibi birçok dış etkeninde değişmesiyle birlikte, insanlar kendilerine bir beslenme şekli oluşturur ve bunu bir hayat boyu sürdürürler. Maalesef olușturulan bu beslenme şekli, çoğu kez yetersiz, dengesiz ve sağlıksız olarak benimsenir.

Yeterli ve dengeli beslenme, insanlarm büyümesi, gelişmesi, varlıklarını sürdürebilmesi ve faaliyetlerini en iyi şekilde yapabilmeleri için gerekli besin öğelerinin alınması olarak tanımlanır İnsanlar, sağlı̆̆ını korumak ve daha iyiye götürebilmek için besinleri doğru miktarlarda, doğru zamanlarda ve bilinçli olarak tüketmelidir. (Alpar, 2011) ${ }^{1}$.

Ekonomik sebepler nedeniyle, insanların çalışma hayatına daha aktif olarak katılması, trafik gibi nedenlerle zaman sorunlardan ve evde geçirilen sürecin azalması nedeniyle, insanların evde yemek hazırlama alışkanlığı ve ev yemeği tüketimi yerini, dişarda geçirilen sürenin daha fazla olmasından dolayı, daha pratik, zaman almayan, sağlıksız fast-food gıdalara bırakmıștır.

20.yy da başlayan ve 21.yy'da devam eden ve hızla artan teknolikleşme ve dijital ilerlemeye paralel olarak, insanlar tüm ihtiyaçlarını, masa başında, bilgisayar karşısında tek tuş ile gerçekleștirebilmektedirler. Tüm bu teknolikleşme ve gelişime paralel olarak, insanlar diğer çağlardan farklı olarak, daha hareketsiz bir yaşam benimsemişlerdir. Daha önceki çağlarda, insanların yaşamlarını ve barınma, avcılık, güvenlik gibi yaşamın temel ihtiyaçlarının yerine getirilmesi için gerekli olan hareket, bu son teknolojikleşme süreciyle oldukça azalmıștır. Beslenme düzeni ve yaşam tarzında meydana gelen tüm bu değişiklikler, başta obezite olmak üzere birçok sağlık sorununu da beraberinde getirmiştir.
Obezite küresel boyutta önemli bir halk sağlığı sorunudur. Hem gelişmiş ülkelerde hem de gelişmekte olan ülkelerde obezite her geçen gün artış göstermektedir. Türkiye Beslenme ve Sağlık Araştırması- 2010 ön çalışma raporuna göre Türkiye'de obezite sıklı̆̆l; kadınlarda $\% 41$, erkeklerde $\% 20,5$ ve genel toplumda ise \%30,3 olarak tespit edilmiştir. (Türkiye Halk Sağlığı Kurumu, "Hastalıklarda Beslenme", http://beslenme.gov.tr/index.php?page $=49$, Erişim: 05 Mart 2016,)².

Ülkemizde de diğer dünya ülkelerinde olduğu gibi obezite görülme sıklığı her gün artış göstermektedir. Sağlık Bakanlığınca gerçekleștirilen "Türkiye Beslenme ve Sağlık Araştırması" raporuna göre ülkemizde obezite sıklığl erkeklerde $\% 20,5$, kadınlarda $\% 41,0$ ve toplamda \%30,3 olarak bulunmuştur. Toplamda fazla kilolu olanlar \%34,6, fazla kilolu ve şişman olanlar $\% 64,9$, çok şişman olanların oranı \%2,9 olarak bulunmuștur. (http://beslenme.gov.tr/index.php?lang=tr\&pa ge=40, Erişim Tarihi: 07 Mayıs 2014) ${ }^{3}$.

Sağlıklı yaşlanmak ve yaşa bağlı oluşabilecek sağlık risklerini en aza indirebilmek için temel etkenler, sağlıklı beslenme ve fiziksel aktivitenin arttırılmasıdır. Günlük düzenli yapılan fiziksel aktivite, sağlıklı beslenme ile birlikte kronik hastalıkların önlenmesindeki en önemli ögedir. (Garibağaoğlu ve ark., 2006) ${ }^{4}$.

Sağlık için egzersizin temel amacl; hareketsiz bir yaşantının neden olduğu organik ve fiziki bozuklukları önlemek, beden sağlığının ana unsuru olan fizyolojik kapasitesini daha ileriye taşımak, fiziksel uygunluğu ve sağlığı uzun yıllar boyunca korumaktır. Gelişmiş ülkelerde başlayarak egzersize olan ilginin artışındaki nedeni biyolojik bir dengeleme ihtiyacı şeklinde açıklamak mümkündür (Günay ve ark., $2008)^{5}$.

Düzenli egzersiz, fiziksel, mental ve emosyonel sağlık için büyük önem taşır. Egzersiz enerji harcanmasını artırır, böylelikle ağırlı̆̆ın korunmasında veya zayıflamada yararlı etkiler 
gösterir. Düzenli egzersiz serum kolesterol ve glikozun normal düzeyde tutulmasını sağlar, yüksek dansitelilipo protein kolestrolünü arttırır. Egzersiz sırasında doğal yatıştırıcılar olarak bilinen endorfinler salgılanır. Düzenli egzersiz, kardiovasküler ve iskeleti sistemini sağlıklı tutar, böylece yaşlanmayı geciktirir. Düzenli egzersiz programlarına başlamadan önce kişilerin, kalp, hipertansiyon, solunum sistemi hastalıkları vb. yönünden kontrolden geçirilmesi gerekmektedir (Selim, 2007) ${ }^{6}$.

$\mathrm{Bu}$ çalışma da; Marmara Üniversitesi Haydarpaşa Kampüsü'nde çalışan öğretim elemanlarının besin tüketim ve fiziksel aktivite düzeylerinin belirlenmesi amaçlanmıştır. $\mathrm{Bu}$ amaç, doğrultusunda planlanan çalışmanın, öğretim elemanları örneklemi özelinde beslenme alışkanlıkları ve fiziksel aktivitelerin belirlenmesi ve yeni çalışmalara örnek olması açısından literatüre katkı sağlayacağı düşünülmektedir.

\section{Beslenme Kavramı}

Günümüzde çoğu insan beslenme denildiğinde, Maslow'un ihtiyaçlar hiyerarşisi pramidinin tabanında bulunan fizyolojik ihtiyaçlar başlığı altında geçen; yeme, içme faaliyetlerini düşünerek, beslenmeyi karın doyurma olarak algllamaktadır. Oysaki beslenme, karın doyurmak ya da açlık duygusunu bastırmak demek değildir.

Beslenme; sağlığı korumak, iyileştirmek, geliştirmek ve yaşam kalitesini yükseltmek için vücudun gereksinimi olan besin öğelerini yeterli ve dengeli miktarlarda ve uygun zamanlarda almak için bilinçli yapılması gereken bir davranıştır. Beslenme, yaşamın sürdürülmesi, sağlığın korunması ve geliştirilmesi için besinlerin tüketilmesi olarak tanımlanmaktadır (Türkiye Çocukluk Çağı Obezite Araştırmasl, 2013)7.

Beslenmede amaç; kişinin yaşı, cinsiyeti, fiziksel aktivitesi ve içinde bulunduğu fizyolojik duruma göre, ihtiyacı olan enerji ve besin öğelerini yeterli ve dengeli miktarlarda almasıdır. Yeterli beslenme, genel olarak vücudun yaşamı ve çalışmasını sürdürebilmesi için gerekli enerjinin sağlanması anlamına gelmektedir. Dengeli beslenme ise enerji yanında bütün besin öğelerinin (karbonhidrat, protein, yağ, vitaminler, mineraller, su)insanın ihtiyacı kadar alınmasıdır (Samur, 2002)8 .

Hem yetersiz beslenme, hem de aşırı beslenme ölümlerin ve hastalıkların oluşumunda ve gelişiminde önemli bir rol oynamaktadır. $\mathrm{Bu}$ sebeple beslenme durumunun saptanması bireyin ve toplumun sağllğının geliștirilmesi için en önemli yapı taşıdır (Pekcan, 2008) ${ }^{9}$.

\section{Obezite Kavramı}

Türkiye'de Sağlık Bakanlığına göre obezite; "genel olarak bedenin yağ kütlesinin, yağsız kütleye oranının aşırı artması sonucu boy uzunluğuna göre vücut ağırlığının arzu edilen düzeyin üstüne çıkmasıdır" ifadesiyle tanımlanmıştır. Yetişkin kadınlarda vücut ağırlığının \%20-25'ini, erkeklerde ise \%1518 'ini yağ dokusu oluşturmaktadır. Bu oranın kadınlarda \%30'un, erkeklerde ise \%25'in üstüne çlkması obezite olarak kabul edilmiștir.(Türkiye Halk Sağlığı Kurumu, "Obezite Nedir?", (t.y.) http://beslenme.gov.tr/index.php?lang=tr\&pag e=38 Erişim: 12 Aralık 2015.) ${ }^{10}$.

Günümüzde, bireylerin ev dişında geçirdikleri zamanın artmasıyla birlikte, yeme-içme alışkanlıkları değişime uğramakta ve yetersiz ve dengesiz beslenme yaşam tarzı haline gelmektedir. Düzensiz ve dengesiz beslenmek, fast-food tarzı yiyecekler tüketmek, spor yapmamak, kilo almaya ve bazı hayati organların da yağlanmasına ve obezite sorununa neden olmaktadır. Günümüze kadar gerçekleştirilen birçok araştırma dünyada olduğu gibi ülkemizde de obezitenin giderek daha önemli bir boyut kazandığını göstermektedir. Ülkemizde de obezite ile mücadele ulusal sağlı politikasına iliş̧in çeşitli yayınlarda yer almıştır. Sağlık 
Bakanlığımızca hazırlanan "Sağlık 21 Herkes İçin Sağlık" programında obezitenin hipertansiyon, diyabet vb. hastalıklar için önemli bir risk faktörü olduğu belirtilmiştir (Türkiye'nin Hedef ve Stratejileri, 2001) ${ }^{11}$. "Türkiye Kalp ve Damar Hastalıklarını Önleme ve Kontrol Programı'nda da pek çok kronik hastalık için risk faktörü olan obezitenin önlenmesi için ulusal bir programın hazırlanması hususu yer almıştır (Türkiye Kalp ve Damar Hastalıklarını Önleme ve Kontrol Programı, 2008) ${ }^{12}$.

Sağlık Bakanlığınca yapılan "Türkiye Beslenme ve Sağlık Araştırması-2010" ön çalışma raporuna göre, Türkiye'de obezite sıklığı; kadınlarda \%41, erkeklerde ise $\% 20,5$ ve toplamda; \%30,3 olarak bulunmuștur. (Türkiye Halk Sağlığı Kurumu, "Türkiye'de Obezitenin Görülme Sıklığı", http://beslenme.gov.tr/index.php?page $=40$. Erişim: 08 Ocak 2016.) ${ }^{13}$.

2010 yılında yapılan TURDEP-II çalışması; 20 yaş üzeri 26499 birey (16696 kadın, 9327 erkek) üzerine yapılmıştır. Bu çalışmaya göre TURDEP-I çalışmasından 12 yıl sonra yapılan TURDEP-II çalıșmasında obezite prevalansı (BKI $30 \mathrm{~kg} / \mathrm{m} 2$ ) kadınlarda \%34, erkeklerde \%107 artış göstermiş̦tir. Obezite, hem erkeklerde hem de kadınlarda 20-24 yaș grubundan itibaren 50-54 yaş grubuna kadar devamlı artış göstermiştir. Bu yaştan sonra ileri yaşlara doğru azalma eğilimine girmektedir. (Satman, İ. ve TURDEP-II Çalıșma Grubu. TURDEP-II Sonuçları. İstanbul Üniversitesi İstanbul Tıp Fakültesi İç Hastalıkları Anabilim Dalı Endokrinoloji ve Metabolizma Hastalıkları Bilim Dalı, 2002, 25:1551-1556.). ${ }^{14}$.

\section{Sağllk ve Beslenme İlişsisi}

Dünyada beslenme ile ilgili sorunlara bakıldığında, başlıca iki temel sorunun olduğu görülmektedir. Bunlardan birincisi, insanların yeterince besin maddesi bulamamasına bağlı açlık sorunu, ikincisi ise, aşırı ve dengesiz beslenmeye bağlı olușan sağlık sorunlarıdır.
Her iki durumda da, insan sağlığı risk altına girebilmekte, dünyanın bazı yerlerinde açlı̆ga bağlı insan ölümleri görülürken, diğer bazı yerlerinde ise aşırı ve dengesiz beslenmeden kaynaklanan sağlık sorunları nedeniyle, insanlar zorluklar yasayabilmektedir. Dolayısıyla, insanların en değerli varlıkları olan sağlıklarını korumak için, yeterli ve dengeli beslenmeye son derece önem vermeleri gerekmektedir (Açıkgöz, 2006) ${ }^{15}$.

Beslenme alışkanlıkları, sağlığımızı çok yakından ilgilendirmektedir. Hatalı beslenme alışkanlıkları obezite, kalp-damar hastalıkları, hipertansiyon, kanser ve diyabet gibi hastalıklara yakalanma riskini arttırmaktadır. $\mathrm{Bu}$ hastalıklardan korunmak, uzun ve sağlıklı bir yaşam şansını arttırmak için mutlaka yeterli ve dengeli beslenmek gerekmektedir. (Sayan, 1999) ${ }^{17}$. Günümüzde birçok kronik hastalığın beslenme ve yaşam şekli biçimleri ile bağlantılı olduğu bilinmektedir. Beslenme unsurları ile yaşam şeklinin; kanserlerin \%30-40'ında; kardiyovasküler hastalıklardan ölümlerin en az 1/3'ünde; şişman ve kilolu olmanın diyabet hastalığının oluşumunda, kardiyovasküler hastalık ve kanser türlerinde artan riskten ölümlerde; osteoporoz ve yaslllarda osteoporoz sonucu görülen kalça kırıkları gibi sonuçların oluşumunda etkili oldukları bilinmektedir. Yine diyet unsurlarının diş çürükleri, demir yetersizliği ve iyot yetersizliği hastalıkları ile ilişkisi de bilinmektedir (Pekcan, 2006) ${ }^{18}$.

Diyabet gelişiminde önemli risk faktörlerinden biri beslenmedir. Özellikle artan obezite prevalansı diyabet sıklığını da arttırmaktadır. Dengeli ve yeterli beslenme kurallarının uygulanması diyabet gelişim riskinin azaltılmasında önemlidir (Attila, 2006) ${ }^{19}$.

Kalp damar hastalıklarının oluşumunda başlıca nedenler; beslenmede doymuş yağların (katı yağlar, margarinler vb.), ağırlıklı tüketimi, aşırı tuz tüketimi, saflaştırılmış (rafine) besinlerin yüksek, diyet posası ve antioksidan öğelerin (sebze ve meyve, tam tahıl ürünlerinin) 
tüketiminin yetersiz olmasıyla birlikte, Obezite sıklıkla hipertansiyonla birlikte hareketsiz yaşam biçimi ve sigara kullanımıdır bulunur ve kilo kaybı ile tansiyon normale (Samur, 2008) ${ }^{20}$.

Tablo 1: Katılımcıların Cinsiyet, Yaş Grupları, Medeni Durum ve Görev Yaptıkları Okullara Göre Dağılımları

\begin{tabular}{|c|c|c|}
\hline Cinsiyet & $\mathbf{S}$ & $\%$ \\
\hline Kadın & 149 & 66,2 \\
\hline Erkek & 76 & 33,8 \\
\hline \multicolumn{3}{|l|}{ Yaş grupları } \\
\hline $18-24$ & 12 & 5,4 \\
\hline $25-34$ & 88 & 39,1 \\
\hline $35-44$ & 64 & 28,4 \\
\hline 44'ün üstü & 61 & 27,1 \\
\hline \multicolumn{3}{|l|}{ Medeni Durum } \\
\hline Bekar & 92 & 40,9 \\
\hline Evli & 125 & 55,6 \\
\hline Boşanmış/eşiölmüş & 8 & 3,5 \\
\hline \multicolumn{3}{|c|}{$\begin{array}{l}\text { Görev yapmakta oldukları } \\
\text { Fakülte ve Yüksekokul } \\
\end{array}$} \\
\hline Tıp Fakültesi & 53 & 23,6 \\
\hline EczacılıkFakültesi & 63 & 28,0 \\
\hline HemşirelikYüksekokulu & 31 & 13,7 \\
\hline HukukFakültesi & 78 & 34,7 \\
\hline \multicolumn{3}{|c|}{$\begin{array}{l}\text { Marmara Üniversitesi'nde } \\
\text { Görev Yaptıkları Süre } \\
\end{array}$} \\
\hline $1-5$ yıl & 88 & 39,1 \\
\hline $6-10$ yll & 24 & 10,7 \\
\hline $11-15$ yll & 38 & 16,9 \\
\hline $16-20$ yll & 34 & 15,1 \\
\hline 21 yılveüzeri & 41 & 18,2 \\
\hline Toplam & 225 & 100,0 \\
\hline
\end{tabular}
dönebilir. Obezitedeki hipertansiyon prevalansı ile ilgili farklı sonuçlar verilmesine rağmen \%40-50'ye varan oranlar mevcuttur. VKI ile hipertansiyon arasında da pozitif bir ilişki vardır. Kilo alma hipertansiyon riskini arttırmakta ve 5-10 kg alanlarda hipertansiyon riski 1,7 kat artarken $25 \mathrm{~kg}$ dan fazla kilo alanlarda ise 5,2 kat daha fazla olmaktadır (Korugan, 2001; Huang ve ark., 1998)21.

Tablo 2: Katılımcıların VKİ Açısından Değerlendirilmesi

\begin{tabular}{lcc}
\hline VKİ grupları & $\mathrm{S}$ & $\%$ \\
\hline Zayıf $(<18,50)$ & 11 & 4,9 \\
\hline Normal kilolu $(18,50-24,99)$ & 132 & 58,6 \\
\hline Fazlakilolu $(25,0-29,99)$ & 67 & 29,8 \\
\hline Obez (30 veüzeri) & 15 & 6,7 \\
\hline Toplam & 225 & $\mathbf{1 0 0 , 0}$ \\
\hline
\end{tabular}

\section{YÖNTEMLER}

Araștırma tanımlayıcı tipte bir araştırmadır. Marmara Üniversitesi Haydarpaşa Kampüsü'ndeki Tıp Fakültesi Temel Bilimleri, Eczacılık Fakültesi, Hemşirelik Yüksekokulu ve Hukuk Fakültesinde Aralık 2013-Nisan 2014 tarihleri arasında görev yapan öğretim elemanları arasında yürütülmüştür. Araştırma kapsamında toplam 225 öğretim elemanına anket uygulanarak araştırma tamamlanmıştır.

Araştırmanın çalışma evrenini; Aralık 2013Mart 2014 tarihleri arasında, İstanbul ili Marmara Üniversitesi Haydarpaşa Kampüsü'ndeki Tıp Fakültesi Temel Bilimlerinde, Eczacılık Fakültesi, Hemşirelik Yüksekokulu ve Hukuk Fakültesinde görev yapan öğretim elemanları oluşturmaktadır. Bu bölümlerde görev yapan öğretim elemanları sayısı 2014 yılında toplam 339 kişi olarak tespit edilmiştir ve yaklaşık \%66,4'üne (225 kişi) ulaşılarak anket uygulanmıştır. 
Tablo 3: Katılımcıların Görev Yerlerine Göre VKİ Gruplarının Dağılımı

\begin{tabular}{|c|c|c|c|c|c|c|c|c|c|c|}
\hline \multirow{3}{*}{ Bölümler } & \multicolumn{8}{|c|}{ VKİ grupları } & & \\
\hline & \multicolumn{2}{|c|}{ Zayıf } & \multicolumn{2}{|c|}{ Normal kilolu } & \multicolumn{2}{|c|}{ Fazla Kilolu } & \multicolumn{2}{|c|}{ Obez } & \multicolumn{2}{|c|}{ Toplam } \\
\hline & $\mathbf{S}$ & $\%$ & $\mathbf{S}$ & $\%$ & $\mathbf{S}$ & $\%$ & $\mathbf{S}$ & $\%$ & $\mathbf{S}$ & $\%$ \\
\hline Tıp Fakültesi & 3 & 5,7 & 31 & 58,5 & 17 & 32,1 & 2 & 3,7 & 53 & 100,0 \\
\hline Eczacılık Fakültesi & 6 & 9,5 & 30 & 47,6 & 21 & 33,3 & 6 & 9,6 & 63 & 100,0 \\
\hline Hemşirelik Yüksekokulu & 2 & 6,5 & 23 & 74,2 & 4 & 12,9 & 2 & 6,4 & 31 & 100,0 \\
\hline Hukuk Fakültesi & 0 & 0,0 & 48 & 61,5 & 25 & 32,1 & 5 & 6,4 & 78 & 100,0 \\
\hline
\end{tabular}

Marmara Üniversitesi Haydarpaşa Kampüsü'nde çalışan öğretim elemanlarına araştırmacı tarafından fakültelere gidilerek yüz yüze anket uygulanmış ve boy ile kiloları standardize edilmiş tartı (Fakir Hercules Vücut Analiz Baskülü;100gr.'a kadar hassas) ve boy ölçme aleti (mezura) ile ölçülmüştür. Kişilerin ölçümleri; ayakta dik biçimde, bacakları hafif aralık ve ağırlığı bacaklara eşit dağıtılmış olarak kalça kaslarını sıkmadan durur pozisyonda yapılmıştır. Veriler, hazırlanan toplam 25 soruluk bir anket formu ve 3 günlük besin tüketim kaydıyla, veriler toplanmıștır. Veri toplama gereci olarak kullanılan anket 3 bölümden oluşmaktadır:

\section{Demografik Bilgiler ve Beslenme} Alışkanlıkları Soruları

\section{Fiziksel Aktivite Soruları}

\section{3. Üç günlük Beslenme Davranışı Formu}

Veriler araştırmacı tarafından SPSS 20,0 paket programında analiz edilmiștir. Gruplararası ortalamalarının karşılaştırılmasında veriler normal dağılım koşullarını karşıladığı için iki ortalama arasındaki farkın önemlilik testi (t test) kullanılmıştır. İstatistiksel anlamlılık düzeyi olarak "p<0,05" kabul edilmiştir. İkiden fazla grupların ortalamaları karşılaştırılırken Anova testi kullanıldı. Farklılık durumlarında ileri analizlerde Post hoc test olarak Tukey testi kullanıldı.
Fiziksel Aktivite değerlendirilirken; Uluslararası Fiziksel Aktivite Değerlendirme Anketi (IPAQ) 15-65 yaş aralığındaki katılımcların fiziksel aktivite düzeylerini belirlemek amacıyla geliştirilmiştir. IPAQ, uluslararası arenada günlük olarak yapılan fiziksel aktiviteyi bireysel raporlara dayanarak fiziksel aktivite düzeyi hakkında geçerli ve karşılaştırılabilir bilgi elde etmek amacıyla geliştirilmiştir. IPAQ geliştirme çalışmaları 1998 yılında Cenevre' de başlamıștır ve bunu 12 ülkede yapılan geçerlik ve güvenirlik çalışmaları izlemiştir. Sonuçlar ölçeğin toplumda fiziksel aktiviteye katılma yaygınlığını gösterebileceğini ve bu amaçla ölçeğin birçok farklı kültür ve ortamda uygulanabileceğini düşündürmüştür. Türkiye' de Öztürk tarafından 2005 yılında üniversitelerde eğitim-öğretim gören öğrencilerde ayrıca Hacettepe Üniversitesi Spor Bilimleri ve Teknolojisi Yüksekokulu Tarafindan 2007 yllında IPAQ anketinin geçerlik ve güvenirlik çalışması yapılmıştır.

Aktivitelerin şiddetleri sinıflandırılırken genellikle MET değerleri kullanılır.

Fiziksel aktivite esnasında tüketilen oksijen miktarını ifade etmek için Metabolic Equivalent (metabolik eşitlik)' in kısaltılmışı olan MET terimi kullanılır. 1 MET dinlenik iken kilogram başına bir dakikada tüketilen yaklaşık $3,5 \mathrm{ml}$ oksijeni ifade eder. Aktiviteden kaynaklanan enerji tüketim miktarının istirahat sırasındaki enerji tüketimine olan oranına MET denir. 
IPAQ Anketinin puanlanması ve skorlaması: Kısa form (7 soru); yürüme, orta şiddetli ve şiddetli aktivitelerde harcanan zaman ve otururken harcanan zaman hakkında bilgi sağlamaktadır.

Kısa formun toplam skorunun hesaplanması yürüme, orta şiddetli aktivite ve şiddetli aktivitenin süre (dakikalar) ve frekans (günler) toplamını içermektedir. Aktiviteler için gerekli olan enerji MET-dakika skoru ile hesaplanır. Bu aktiviteler için standart MET değerleri oluşturulmuştur. Bunlar;

Yürüme = 3.3 MET,

Orta Şiddetli Fiziksel Aktivite $=4.0$ MET,

Şiddetli Fiziksel Aktivite = 8.0 MET,

Oturma $=1.5$ MET.

Yürüme MET-dk/hafta = 3.3 X yürüme dakikası $\mathrm{X}$ yürüme gün sayısı

Orta şiddetli MET-dk/hafta $=4.0 \mathrm{X}$ orta şiddetli aktivite dakikası $\mathrm{X}$ orta şiddetli aktivite gün sayısı

şiddetli MET-dk/hafta $=8.0 \mathrm{X}$ şiddetli aktivite dakikası $\mathrm{X}$ şiddetli aktivite gün sayısı

$\mathrm{Bu}$ değerler kullanılarak günlük ve haftalık fiziksel aktivite seviyesi hesaplanır.

VKİ grup Değerlendirmesi; VKİ: (boy uzunluğu (cm))2/ Kilo (ağırlık) (kg)

Zayıf VKİ $<18,5$

Normal Kilolu 18,5 < VKI $<24,9$

Fazla Kilolu $25<$ VKI $<29,9$

Obez VKİ<30'un üstü Olarak değerlendirilir.

\section{BULGULAR}

Araştırma grubundaki öğretim elemanlarının \%66,2'si kadın, \%33,8'i erkektir. Araştırma grubunun \%5,4'ü 18-24 yaş grubunda , \%39,1'i 25-34 yaş grubunda, \%28,4'ü 35-44 yaş grubunda, \%27,1'i 44 üzeri yaş grubundadır. Katılımcıların yarıdan fazlası $(\% 55,6)$ evlidir. Katılımcıların görev yapmakta olduğu fakülteler ve yüksekokul incelendiğinde; \%23,6'sının Tıp Fakültesi'nde, \%28,0'ının Eczacılık Fakültesi'nde, \%13,7'sinin Hemşirelik Yüksekokul' unda ve \%34,7'sinin Hukuk Fakültesi'nde görev yapmakta olduğu bulunmuştur. Marmara Üniversitesi'nde görev yaptıkları süre incelendiğinde; \%39,1'i 1-5 yıl ve \%18,2'si 20 yıl ve daha fazla süredir Marmara Üniversitesi'nde görev yapmakta olduklarını belirlenmiştir.

Katılımcıların VKİ değerleri <18,50 zayıf, 18,50 - 24,99 normal kilolu, 25 - 29,99 fazla kilolu, 30 ve üzeri ise obez olarak yapılan sınıflandırmaya göre incelendiğin de; \%4,9'u zayıf , \%58,6'sı normal kilolu , \%29,8'i fazla kilolu ve \%6,7'si obez olarak bulunmuştur. Fazla kilolu ve obezler birlikte değerlendirildiğinde öğretim elemanlarının \%41,4'ünün kilosunun normalin üzerinde olduğu görülmektedir.

Katılımcıların VKİ grupları ile görev yapmakta oldukları Fakülte/Yüksekokul arasında istatistiksel olarak anlamlı farklılık vardır $(p<0,05)$. Obezite oranı en yüksek bölüm; Eczacılık Fakültesinde iken $(\% 9,6)$, bu oran Tıp Fakültesi öğretim üyelerinde $\% 3,7$ ile daha düşüktür. Hukuk Fakültesinde hiç zayıf katılımcı yoktur. Kilosu normalin üzerinde olanların oranı \%33,3 ile Eczacılık Fakültesinde en yüksek iken, Hemşirelik Yüksekokulunda bu oran \%12,9 ile en düşüktür. Obezite bakımından en yüksek oran \%9,6 ile Eczacılık Fakültesinde iken, en düşük oran \%3,7 ile Tıp Fakültesindedir.

Katılımcıların öğün atlama durumlarına göre dağılımları incelendiğinde; öğretim elemanlarının önemli bir oranının \%72,0'ı sürekli öğün atladığı görülmektedir. Bazen ögün atlayanlarda dikkate alındığında bu oran \%94,7’ye çıkmakta, öğün atlamayanların oranı çok düşük kalmaktadır.

Öğün atlama açısından; katılımcıların \%22,7'lik kısmı bazen öğün atladığını belirtirken, Tıp Fakültesi \%77,4 ile diğer bölümlere göre daha 
fazla öğün atlayan katılımcıya sahip iken bölümler arasında öğün atlama durumu bakımından istatiksel olarak anlamlı farklılık bulunmamaktadır ( $p>0,05)$.

Tablo 4:Katılımcıların Öğün Atlama Durumlarına Göre Dağılımı

\begin{tabular}{lcc}
\hline Öğün atlama & S & $\%$ \\
\hline Evet & 162 & 72,0 \\
Hayır & 12 & 5,3 \\
Bazen & 51 & 22,7 \\
Toplam & 225 & $\mathbf{1 0 0}$ \\
\hline
\end{tabular}

Katılımcıların görev yaptıkları bölümlere göre yağ alım değerleri arasında istatistiksel olarak anlamlı fark bulunmuştur $(p<0,05)$. Tıp Fakültesi $(71,7 \pm 35,29)$ en yüksek yağ alımına sahip bölüm iken, Hukuk Fakültesi $(57,8 \pm 17,72)$ günlük en düşük yağ alımına sahip bölümdür. Eczacıllk Fakültesi'nin günlük kalori $(1420,53 \pm 337,26)$ ve protein alımı $(85,5033,66)$, diğer bölümlere göre daha yüksek iken, Tıp Fakültesinin günlük karbonhidrat alımı $(123,6 \pm 46,11)$ diğer bölümlere göre daha yüksektir. Ancak istatistiksel olarak anlamlı fark bulunmamıștır ( $p>0,05)$.

Katılımcıların alanlarına göre günlük kalori ve yağ alım değerleri arasında istatiksel olarak anlamlı fark vardır $(\mathrm{p}<0,05)$. Sağlık alanında görev yapanlar en yüksek günlük kalori $(1388,9$ ?332,65) ve yă alımına $(68,5$ (26,02) sahip grup iken, Hukuk alanında görev yapanlar en düşük günlük kalori $(1282,5$ ?326,44) ve yă̆ alımına $(57,8$ 回17,85) sahiptir. Sağlık alanında görev yapanların günlük karbonhidrat $(117,4$ 回 37,82$)$ ve protein alımları (79,7国31,61) Hukuk alanında görev yapanlara göre daha yüksek iken bunlar arasinda istatistiksel olarak anlamlı fark yoktur $(\mathrm{p}>0,05)$.

Öğretim üyelerinin aktivite düzeyi değerlendirildiğinde \% 66,7'sinin in aktif olduğu görülmüştür. Minimal düzeyde aktif olanların oranı \% 30,7 iken çok aktif olanların oranı yalnızca \% 2,6'dır.

\section{SONUÇ}

Araştırmaya katılan 225 öğretim elemanın da ; \%66,2'si kadın, \%33,8'i erkektir.

Katılımcıların, \%23,6'sının Tıp Fakültesi'nde, \%28,0'ının Eczacıllk Fakültesi'nde, \%13,7'sinin Hemşirelik Yüksekokul' unda ve \%34,7'sinin Hukuk Fakültesi'nde görev yapmakta olduğu bulunmuştur.

Katılımcıların ; \%4,9'u zayıf , \%58,6'sı normal kilolu , \%29,8'i fazla kilolu ve \%6,7'si obez olarak bulunmuștur. Fazla kilolu ve obezler birlikte değerlendirildiğinde öğretim elemanlarının \%41,4'ünün kilosunun normalin üzerindedir.

Obezite oranı en yüksek bölüm; Eczacılık Fakültesinde iken $(\% 9,6)$, bu oran Tıp Fakültesi öğretim üyelerinde \%3,7 ile daha düșüktür. Hukuk Fakültesinde hiç zayıf katılımcı yoktur. Kilosu normalin üzerinde olanların oranı $\% 33,3$ ile Eczacllık Fakültesinde en yüksek iken, Hemșirelik Yüksekokulunda bu oran \%12,9 ile en düşüktür. Obezite bakımından en yüksek oran \%9,6 ile Eczacılık Fakültesinde iken, en düşük oran \%3,7 ile Tıp Fakültesindedir.

Katılımcıların \%72,0'sinin sürekli öğün atladığı görülmektedir. Bazen öğün atlayanlarda dikkate alındığında bu oran \% 94,7'ye çıkmakta, öğün atlamayanların oranı çok düşük kalmaktadır.

Tıp Fakültesi $(71,7 \pm 35,29)$ en yüksek yağ alımına sahip bölüm iken, Hukuk Fakültesi $(57,8 \pm 17,72)$ günlük en düşük yağ alımına sahip bölümdür. Eczacılık Fakültesi'nin günlük kalori $(1420,53 \pm 337,26)$ ve protein alımı $(85,5 \pm 33,66)$, diğer bölümlere göre daha yüksek iken, Tıp Fakültesinin günlük karbonhidrat alımı $(123,6 \pm 46,11)$ diğer bölümlere göre daha yüksektir. 
Tablo 5:Katılımcıların Bölümlere Göre Öğ̈n Atlama Durumları

\begin{tabular}{|l|c|c|c|c|c|c|c|c|}
\hline \multicolumn{2}{|c|}{ Ovet } & \multicolumn{2}{c|}{ Hayır } & \multicolumn{2}{c|}{ Bazen } & \multicolumn{2}{c|}{ Toplam } \\
\hline Bölümler & $\mathbf{S}$ & $\mathbf{9}$ & $\mathbf{S}$ & $\mathbf{\%}$ & $\mathbf{S}$ & $\%$ & $\mathbf{S}$ & $\%$ \\
\hline Tıр Fakültesi & 41 & 77,4 & 3 & 5,6 & 9 & 17,0 & 53 & 100,0 \\
\hline Eczacılık Fakültesi & 42 & 66,7 & 5 & 7,9 & 16 & 25,4 & 63 & 100,0 \\
\hline Hemşirelik Yüksekokulu & 23 & 74,2 & 1 & 3,2 & 7 & 22,6 & 31 & 100,0 \\
\hline Hukuk Fakültesi & 56 & 71,8 & 3 & 3,8 & 19 & 24,4 & 78 & 100,0 \\
\hline Toplam & $\mathbf{1 6 2}$ & $\mathbf{7 2 , 0}$ & $\mathbf{1 2}$ & $\mathbf{5 , 3}$ & $\mathbf{5 1}$ & $\mathbf{2 2 , 7}$ & $\mathbf{2 2 5}$ & $\mathbf{1 0 0 , 0}$ \\
\hline
\end{tabular}

Tablo 6:Katılımcıların Görev Yaptıkları Bölümlere Göre Günlük Kalori, Karbonhidrat, Protein ve Yağ Alım Değerleri

\begin{tabular}{|l|c|c|c|c|c|}
\hline Görev yaptıkları bölümler & $\mathbf{n}$ & $\begin{array}{c}\text { Kalori } \\
\text { Ort } \pm \text { SS }\end{array}$ & $\begin{array}{c}\text { Karbonhidrat } \\
\text { Ort } \pm \text { SS }\end{array}$ & $\begin{array}{c}\text { Protein } \\
\text { Ort } \pm \text { SS }\end{array}$ & $\begin{array}{c}\text { Yağ } \\
\text { Ort } \pm \text { SS }\end{array}$ \\
\hline Tıр Fakültesi & 53 & $1392,3 \pm 359,41$ & $123,6 \pm 46,11$ & $74,3 \pm 32,71$ & $71,7 \pm 35,29$ \\
\hline Eczacılık Fakültesi & 63 & $1420,53 \pm 337,26$ & $117,3 \pm 32,35$ & $85,9 \pm 33,66$ & $67,4 \pm 20,48$ \\
\hline Hemşirelik Yüksekokulu & 31 & $1318,9 \pm 268,87$ & $106,9 \pm 30,37$ & $76,1 \pm 22,87$ & $65,3 \pm 15,74$ \\
\hline Hukuk Fakültesi & 78 & $1282,5 \pm 326,44$ & $114,9 \pm 41,32$ & $76,5 \pm 28,58$ & $57,8 \pm 17,72$ \\
\hline & & $\mathbf{F = 2 , 4 1}$ & $\mathbf{F = 1 , 2 7}$ & $\mathbf{F = 1 , 7 7}$ & $\mathbf{F = 4 , 1 1}$ \\
& & $\mathbf{p}>\mathbf{0 , 0 5}$ & $\mathbf{p}>\mathbf{0 , 0 5}$ & $\mathbf{p}>\mathbf{0 , 0 5}$ & $\mathbf{p}<\mathbf{0 , 0 5}$ \\
\hline
\end{tabular}

Ort: Ortalama,

SS: Standart Sapma

Tablo 7: Katılımcıların Alanlarına Göre Kalori, Karbonhidrat, Protein ve Günlük Yağ Alım Değerleri

\begin{tabular}{|l|c|c|c|c|c|}
\hline Alanlar & $\mathbf{n}$ & $\begin{array}{c}\text { Kalori } \\
\text { Ort } \pm \text { SS }\end{array}$ & $\begin{array}{c}\text { Karbonhidrat } \\
\text { Ort } \pm \text { SS }\end{array}$ & $\begin{array}{c}\text { Protein } \\
\text { Ort } \pm \text { SS }\end{array}$ & $\begin{array}{c}\text { Yag } \\
\text { Ort } \pm \text { SS }\end{array}$ \\
\hline Sağlık & 147 & $1388,9 \pm 332,65$ & $117,4 \pm 37,82$ & $79,7 \pm 31,61$ & $68,5 \pm 26,02$ \\
\hline Hukuk & 78 & $1282,5 \pm 326,44$ & $114,9 \pm 41,32$ & $76,5 \pm 28,35$ & $57,8 \pm 17,85$ \\
\hline & & $\mathbf{t = 2 , 3 1}$ & $\mathbf{t = 0 , 4 4 p > 0 , 0 5}$ & $\mathbf{t = 0 , 7 6} \mathbf{p}>\mathbf{0 , 0 5}$ & $\mathbf{t = 3 , 6 5 p < 0 , 0 1}$ \\
\hline
\end{tabular}

Ort: Ortalama, SS: StandartSapma

Tablo 8:Katılımcıların Fiziksel Aktivite Düzeyleri

\begin{tabular}{lcc}
\hline Fiziksel Aktivite Düzeyi & S & $\%$ \\
\hline In aktif & 150 & 66,7 \\
\hline Minimal Aktif & 69 & 30,7 \\
\hline Çok aktif & 6 & 2,6 \\
\hline Toplam & 225 & $\mathbf{1 0 0 , 0}$ \\
\hline
\end{tabular}


Sağllk alanında görev yapanlar en yüksek günlük kalori $(1388,9 \pm 332,65)$ ve yağ alımına $(68,5 \pm 26,02)$ sahip grup iken, Hukuk alanında görev yapanlar en düşük günlük kalori $(1282,5 \pm 326,44)$ ve yağ alımına $(57,8 \pm 17,85)$ sahiptir.

Sağlık alanında görev yapanların günlük karbonhidrat $(117,4 \pm 37,82)$ ve protein alımları $(79,7 \pm 31,61)$ Hukuk alanında görev yapanlara göre daha yüksektir.

Öğretim üyelerinin aktivite düzeyi değerlendirildiğinde \% 66,7'sinin in aktif olduğu görülmüştür. Minimal düzeyde aktif olanların oranı \% 30,7 iken çok aktif olanların oranı yalnızca \% 2,6'dır.

Çıkar Çatışması Beyanı: Yazarlar çıkar çatışması olmadığını bildirmişlerdir.

Finansal Destek: Bu çalışma her hangi bir fon tarafından desteklenmemiştir.

Declaration of Conflicting Interests: The authors declare that they have no conflict of interest.

Financial Disclosure: No financial support was received.

\section{KAYNAKLAR}

1. Alpar F. Vücut Geliştirme Sporcularında Beslenme, Fiziksel Aktivite ve Besin Takviyesi Kullanım Durumlarının İncelenmesi, Hacettepe Üniversitesi, Yüksek Lisans Tezi, 2011, Ankara. SBE. s: 3.

2. Türkiye Halk Sağlığı Kurumu, "Hastalıklarda Beslenme", http://beslenme.gov.tr/index.php?page=49, Erişim: 05 Mart 2016

3. http://beslenme.gov.tr/index.php?lang=tr\&page $=40$, Erişim Tarihi: 07 Mayıs 2014

4. Garibağaoğlu M, Budak N, Öner N, Sağlam Ö, Nişli K. Üç Farklı Üniversitede Eğitim Gören Kız Öğrencilerin Beslenme Durumları ve Vücut Ağırlıklarının Değerlendirilmesi. Sağlıklı Bilimleri Dergisi; 2006;15:173-80.

5. Günay M, Şıktar E, Şıktar E, Yazıcı M. Egzersiz ve Kalp. Gazi Kitapevi Ankara; 2008, s:37-57.
6. Selim İ. Acemi Askerlerde Üç Aylık Eğitim Dönemindeki Beslenme ve Askeri Eğitimin Kan Lipid Değerleri Üzerine Etkisi. Selçuk Üniversitesi Yüksek Lisans Tezi; 2007, Konya. s:21.

7. Türkiye Çocukluk Çağı Obezite Araştırması, 2013.

8. Samur G. İşçi ve İş Veriminin Geliştirilmesinde Beslenmenin Önemi. İș Hukuku ve İktisat Dergisi, 2002. $\mathrm{s}: 1$.

9. Pekcan G. Beslenme Durumunun Saptanması. Sağlık Bakanlığı Yayınları, Ankara; 2008, Yayın No: 732.

10. Türkiye Halk Sağlığı Kurumu, “Obezite Nedir?”, (t.y.) http://beslenme.gov.tr/index.php?lang=tr\&page=38

Erişim: 12 Aralık 2015.

11. Türkiye'nin Hedef ve Stratejileri, 2001.

12. Türkiye Kalp ve Damar Hastalıklarını Önleme ve Kontrol Programı, 2008.

13. Türkiye Halk Sağlığı Kurumu, “Türkiye'de Obezitenin Görülme Siklığı", http://beslenme.gov.tr/index.php?page=40. Erişim: 08 Ocak 2016.

14. Satman, İ. ve TURDEP-II Çalışma Grubu. TURDEP-II Sonuçları. İstanbul Üniversitesi İstanbul Tıp Fakültesi İç Hastalıkları Anabilim Dalı Endokrinoloji ve Metabolizma Hastalıkları Bilim Dalı, 2002, 25:1551-6.

15. Açlkgöz S. Üniversite Öğrencilerinin Beslenme Alışkanlıkları ile Öz Yetkinlik ve İyimserlik İlişkisi: Ankara Üniversitesi Örneği. A.Ü. Sağlık Bilimleri Enstitüsü, Ankara; 2006. s: 8.

16. Sayan A. Beslenme Alışkanlıkları ve Temel Besin Gereksinimleri, Atatürk Üniversitesi Hemşirelik Yüksekokulu Dergisi, Erzurum, 1999:2;53-66.

17. Sayan A. Beslenme Alışkanlıkları ve Temel Besin Gereksinimleri, Atatürk Üniversitesi Hemşirelik Yüksekokulu Dergisi, Erzurum, 1999:2;53-66.

18. Pekcan G. Sağlıklı Yasam Biçimi ve Diyet Kalitesi: Sağlıklı Diyet Göstergeleri. 5. Uluslararası Beslenme ve Diyetetik Kongresi. Ankara; 2006:59-60,

19. Attila S. Kronik ve Dejeneratif Hastalıklarda Beslenme. İçinde: Halk Sağlığı Temel Bilgiler. Ed: Güler Ç, Akın L. 1. Baskı, Hacettepe Üniversitesi Yayınları, Ankara; 2006:s:823-4.

20. Samur G. Kalp Damar Hastalıklarında Beslenme. T.C. Sağlık Bakanlığı Yayınları. Sinem Matbaacılık, Ankara, 2008. s:1-18.

21. Korugan Ü. Obezite. Aktüel Tıp Dergisi. 2001:6:2;113:63-73. 